\title{
Rational Emotive Behavior Therapy (REBT) Guidelines To Reduce Student Aggressiveness
}

\author{
Dewi Aswira Putri ${ }^{1}$, Taufik², Verlanda Yuca ${ }^{3}$, Frischa Meivilona Yendi ${ }^{4}$ \\ ${ }^{1234}$ Universitas Negeri Padang \\ *) Correspondence author, e-mail: aswiradewi@gmail.com
}

\begin{abstract}
Aggressive behavior is a negative action that is intentionally done by individuals who try to hurt others both physically and verbally. There are many factors that influence adolescent aggression, ridicule, conflict in the family, unfavorable school environment, audio-visual media that show scenes of violence and individual perceptions of the environment. This aggressive behavior will affect the lives of individuals themselves and others. Based on this, guidance and counseling is very important to reduce the aggressive behavior of students. One of the guidance and counseling services that can be given group guidance by asking for rational emotive behavior (REBT). With this service, students are expected to behave positively according to applicable norms and not harm others.
\end{abstract}

Keywords: Aggressive, group guidance, rational emotive behavior therapy (REBT).

Article History: Received on 05/09/2019; Revised on 05/10/2019; Accepted on 07/11/2019; Published Online: $15 / 11 / 2019$.

(1) This is an open access article distributed under the Creative Commons Attribution License, which permits unrestricted use, cc) $\quad$ distribution, and reproduction in any medium, provided the original work is properly cited. C2019 by author.

\section{INTRODUCTION}

Teenagers are individuals who start moving from the childhood phase into the early adult phase. At this time individuals change a lot, from biological, cognitive and socialemotional changes (Santrock, 2007). In adolescence there are many problems that arise in the individual or from the environment. Changing issues are difficult for adolescents with the environment and are also confused about finding identity. Associated with the process of self-discovery that adolescents try to show positive things, but the majority of adolescents behave to fight for the values and norms that exist to acknowledge their environment. Where the behavior shown is negative behavior, one of them is aggressive behavior (Prayitno, 2006).

According to Moore and Fine (Koeswara, 1998) Aggressive behavior is an act of violence that is deliberately carried out against certain people or objects, both physically and verbally. This behavior is done intentionally to hurt others. Behaviors that appear such as: hitting, kicking, cursing, mocking, and saying harsh words. This behavior does not occur automatically, but there are a number of factors that underlie a person to behave aggressively. According to Kartono (1998) the factors that influence aggressiveness are the first, external factors such as: ridicule, conflict in the family, unfavorable school 
environment, audio-visual media that broadcast scenarios of violence. Second, internal factors, such as: individual perceptions of the environment.

Based on several studies, there are several factors that cause student aggressiveness such as frustration, leadership and compliance, provocation and temperature (Restu and Yusri, 2013), emotional maturity (Annisavitry, 2017), self control (Auliya and Desi, 2014), gender differences (Aulya, Asmidir and Ifdil, 2016), broken family environment (Pratama, Syahniar and Yeni, 2016), lack of parental attention, poor modeling, and motivation for revenge (Yanizon and Vina, 2019).

Aggressive behavior of students in schools has become a problem that must be resolved immediately because it has led to acts of crime. The situation is seen from the habits that are free and do not think about the values and norms that apply in society. Many problems are encountered in the field, such as a number of students who deliberately hurt others, such as pinching, hitting, kicking, mocking, and ridiculing. This behavior is not only done for friends, but also done for teachers, such as: against the teacher, harsh words, and to ridicule the teacher while learning. This behavior causes physical or psychological injury to the victim.

The aggressive behavior carried out by these students cannot be tolerated any more which will have a hasty effect on the victims and also have an impact on the next generation of nations. Who became adolescents as a generation that embodies the ideals of the Indonesian nation, currently the morale of the nation's children has declined. Based on the problems that have been explained, BK / Counselor teachers in schools can provide services to students, namely group guidance using rational emotive behavior reduces student aggressiveness behavior.

Rational Emotional Behavior Therapy is one approach to counseling conducted by the counselor to his client, which aims to improve the client's mind from irrational to rational through learning, emotions, cognitive and behavior. It is hoped that with the help of this REBT group service, negative thoughts of students who oppose their emotions, can turn into more rational thinking. Can be used to reduce student aggressiveness.

\section{Aggressiveness}

The aggressive word comes from the Latin word uggred which means attack. This word means the readiness of an individual to carry out attacks and impose his will on others or certain objects. This behavior can hurt others physically and psychologically (Pieter et al, 2011: 74). Aggressive behavior is emotional outrage directed at another person or an object for its failure, the action taken is intentional with the form of words and behavior (Susantyo, 2011).

This aggressive behavior is not only in the form of physical hurting behavior, but also in verbal form which results in psychological injury to the victims. Forms of aggressive behavior carried out by students such as hitting, kicking, pinching, ridiculing, and speaking harshly with the teacher. Buss and Perry (1992) that aggressive behavior is classified as being physically aggressive, verbal, angry, and hostile. Verbally aggressive behavior such as: hurting others by using words / verbal. Aggressive angry behavior such 
as: losing patience and not being able to control anger. While hostility such as: hate, suspicion, envy to others, and feel unfair in his life.

Baron (in Hoaken \& Stewart, 2003) that "Aggression is any behavior directed at the purpose of injuring or injuring other living beings who are motivated to avoid such treatment". Based on some of these statements it can be concluded that aggressive behavior is a negative behavior of an individual to attack, hurt, hurt others, both physically and verbally, thus making the victim physically or psychologically injured.

Aggressive behavior does not arise spontaneously, but arises because there are factors that influence it. According to Kartono (1998) aggressive behavior in the background by: 1) external factors, such as taunts from friends, conflicts in the family, unfavorable school environments, audio-visual media that display scenes to feel at home. 2) internal factors, such as an individual's perception of the environment. Besides not getting attention by the environment, feeling depressed, and bad relationships

Based on the results of Restu and Yusri's (2013) research on studies of students' aggressive behavior, there are several individual factors of aggressive behavior, namely in a state of frustration, power and compliance, provocation and air temperature. Furthermore, the factors that influence a person behaves aggressively due to family circumstances.

Based on the results of Pratama, Syahniar, and Yeni's (2016) research regarding aggressive behavior of students from broken home families, an aggressive behavior is caused by a broken family situation or conflict in the family. Children who have problems in the family are more likely to engage in aggressive behavior. In addition, Anggraini's research results (2017) stated the factors that influence this aggressive behavior from the intensity of watching violent shows and parenting patterns of parenting that are less effective. The higher the intensity of someone watching shows of violence and parenting parents who are not effective, the higher the aggressive behavior that is done. Besides the factors that influence aggressive behavior also from the use of illegal drugs (drugs). where when someone experiences poor impulse control can be exacerbated by the effects of illegal drugs, thereby increasing the risk that individuals with poor impulse control will make someone behave aggressively when impulses arise (Moeller et al., 2002).

Based on research by Yanizon and Vina (2019) regarding the causes of the student aggressive behavior, there are several factors, namely internal and external factors, the details are as follows:

1. Internal factors: poor individual self-control, frustration, and gender differences.

2. External factors: broken home / out of harmony family environment, lack of attention from both parents, and poor modeling.

Based on the results of research and expert opinion can be concluded that students do aggressive behavior does not arise by itself, but there are factors that influence it, namely the state of self that feels unnoticed, feel depressed, frustrated, emotional maturity, family conditions that are not harmonious, social environment that is bad and a few other things. 


\section{Group Guidance}

Group guidance is one of the guidance and counseling services provided to students in group situations, to provide information and discuss issues that are educational, work, personal and social (Nurhisan, 2005: 23). This group guidance service aims to prevent the occurrence of problems and difficulties in students' daily lives.

Prayitno and Erman (2004) suggest that group guidance is an information activity carried out to a group of students to help them in making appropriate plans and decisions, so that a group of students becomes strong and independent in life. Group guidance allows students to gain various insights and knowledge from the counselor / counselor teacher who is useful for the daily life of individuals, whether he is a student at school, family members and the community, and he can use it for guidance in making decisions.

Group guidance certainly has the goal of giving insight and finding solutions to a problem together, creating intimacy between group members, growing the courage of group members in expressing opinions, training group members to communicate well, developing real attitudes to achieve things things to be achieved in groups or problem solving of the topics discussed.

\section{Rational emotive behavior (REBT)}

REBT is an approach given to clients to help clients change their views and beliefs from irrational to rational, helping to change attitudes, ways of thinking, and wrong perceptions. So with this approach the client is expected to be able to achieve realization and live life effectively and optimally. According to Komalasari et al (2011) REBT approach focuses on individual behavior, where problematic behavior is caused by irrational thinking. REBT is a directive approach, because this approach re-learns students/clients to understand cognitive input that causes emotional disturbances that affect their behavior.

The Rational Emotive Behavior Therapy approach views that an individual who has a problem is not caused by the environment and his feelings, but rather his beliefs and the way he views the environment. Individual emotional disturbances will affect one's beliefs, which he can assess and interpret what happens to him. Therefore, if someone's emotions are disturbed, then his mind is also disturbed, so that it can lead to the emergency of irrational thinking.

According to Corey (2009) there are two objectives of the REBT approach namely general goals and basic objectives. Where the general goal is to teach clients how to separate behavior evaluations from self-evaluation of its essence and totality and teach clients how to accept all their deficiencies. Whereas the basic aim is to teach clients to change emotional dysfunction into good and healthy behavior. In addition, the purpose of the Rational Emotive Behavior Therapy approach is to help the counselee to recognize and understand his irrational feelings, thoughts and behavior.

Aggressive behavior is an overflow of an individual's transition to failure, which is manifested in the form of damage, attacks, injuring others, both physically and verbally, thus making the victim physically or psychologically injured. This problem is commonly 
found in schools, such as opposing teachers, fighting with fellow students, encouraging the shortcomings of others, challenging friends while studying, kicking friends, against teachers, saying rude to teachers or with other students, and so on. This behavior will adversely affect the victim. Students who experience physical difficulties (disrupted and beaten) by injuries can be injured and also injured due to trauma for the victim.

Based on this it seems that guidance and counseling is very important to reduce the problems done by students. One of the guidance and counseling services that can reduce student aggressiveness is group guidance by using Rational Emotional Behavior Therapy (REBT). This service has proven to be effective in reducing aggressive students in school, as evidenced by the results of several studies conducted by Fahmi and Abd (2019) on Islamic Counseling Guidance Using Rational Emotive Behavior of Theraphy Nature in Tropodo Sidoarjo, the problem of aggressive protection in students can be reduced by students use group guidance services with REBT approval. The existence of this service succeeded in making positive towards students, reducing aggressive challenges to students, even opposing the consideration of responsibility by students. Another study conducted by Kumar (2009) titled The Impact of Rational-Emotive Behavior Therapy (REBT) on Adolescents with Behavior Disorders (CD) referred to as Rational Emotive Behavior Therapy can be done in ways that are adjusted by adolescents.

Rational Emotive Behavior Therapy (REBT) group guidance therapy has a goal that helps students who think they are able to live more productively with rational thinking. By presenting this service, students can correct erroneous thinking in order to correct unexpected conversations, train students to change irrational thoughts and behaviors that can damage themselves, make students more receptive and protect themselves, others, and the environment adjacent.

\section{CONCLUSION}

Based on the discussion above, it can be concluded that counseling guidance that can be given, namely group guidance assistance with the support of Emotional Behavior Therapy (REBT), has proven effective in reducing aggressive student behavior, as discussed in several relevant studies.

\section{REFERENCES}

Anggraini, yunita. (2017). Pengaruh Intensitas Menonton Tayangan Kekerasan dan Pola Asuh Orang Tua Terhadap Perilaku Agresifitas Remaja. Psikoborneo. Vol. 5 (4).

Annisavitry, Yadinda. (2017). Hubungan Antara Kematangan Emosi dengan Perilaku Agresifitas Remaja. Character. Vol. 4 (1).

Auliya, M dan Desi Nurwidawati. (2014). Hubungan Kontrol Diri dengan Perilaku Agresi Pada Siswa SMA Negeri 1 Padangan Bojonegoro. Character. Vol. 2 (3).

Aulya, A., Asmidir I, dan Ifdil. (2016). Perbedaan Perilaku Agresif Siswa Laki-Laki Dan Perempuan. Jurnal Educatio. Vol. 2 (1).

Buss, A.H \& Perry, M. (1992). The Aggression Questionnaire. Journal of Personality and Social Psychology. Vol. 63 (3). 
Corey, Gerald Corey. (2013). Teori dan Praktek Konseling dan Psikoterapi. Alih Bahasa: E. Koswara. Bandung: Refika Aditama.

Fahmi, Lukman dan Abd. Basyid. (2019). Bimbingan Konseling Islam dengan Menggunakan Rational Emotif Behavior Theraphy dalam Menangani Perilaku Agresif Anak Di SD Al-Falah Assalam Tropodo Sidoarjo. Proceeding Of International Conference On Da'Wa And Communication. Vol. 1 (1).

Hoaken, P. N., \& Stewart, S. H. (2003). Drugs Of Abuse And The Elicitation Of Human Aggressive Behavior. Addictive behaviors. Vol. 28 (9).

Kartono, Kartini. (1998). Peranan Keluarga Memandu Anak. Jakarta: Raja Grafindo Persada.

Koeswara, E. (1998). Agresi Manusia. Bandung: Eresco.

Komalasari, Gantina dkk. (2011). Teori dan Teknik Konseling. Jakarta: Indeks.

Kumar, venkatesh G. (2009). Impact of Rational-Emotive Behaviour Therapy (REBT) on Adolescents with Conduct Disorder(CD). Journal of the Indian Academy of Applied Psychology. Vol. 35.

Moeller, F.G Et Al. (2002). Increased Impulsivity In Cocaine Dependent Subjects Independent Of Antisocial Personality Disorder And Aggression. Drug And Alcohol Dependence. Vol. 68. (1)

Nurhisan, Achmad Juntika. (2005). Strategi Layanan Bimbingan \& Konseling. Bandung: Refika Aditama.

Pieter, H.Z dkk. (2011). Pengantar Psikopatologi untuk Keperawatan. Jakarta: Kencana.

Pratama, Randi, Syahniar, dan Yeni K. (2016). Perilaku Agresif Siswa dari Keluarga Broken Home. Juranl Konselor. Vol. 5 (4).

Prayitno dan Erman Amnti. (2004). Dasar-Dasar Bimbingan dan Konseling. Jakarta: Rineka Cipta.

Prayitno, Elida. (2006). Psikologi Perkembangan Remaja. Padang: UNP Press.

Restu, Yoshi dan Yusri. (2013). Studi Tentang Perilaku Agresif Di Sekolah. Jurnal Ilmiah Konseling. Vol. 2 (1).

Santrock, John W. (2007). Adolescent (Remaja). Alih Bahasa: Beneditctine Widyasinta. Jakarta: Erlangga.

Susantyo, B. (2011). Memahami Perilaku Agresif: Sebuah Tinjauan Konseptual. Jurnal Informasi. Vol. 16 (03).

Yanizon, Ahmad dan Vina Sesriani. (2019). Penyebab Munculnya Perilaku Agresif Pada Remaja. Jurnal Kopasta. Vol. 6 (1). 